Original paper

\title{
Petrogenesis of silica-rich carbonatites from continental rift settings: A missing link between carbonatites and carbonated silicate melts?
}

\author{
Lukáš ACKERMAN1,2*, Vladislav RAPPRICH², Ladislav POLÁK'1,3, Tomáš MAGNA², \\ Virginia T. MCLEMORE ${ }^{4}$, Ondřej POUR², Bohuslava ČEJKOVÁ ${ }^{2}$
}

\author{
${ }^{1}$ Institute of Geology of the Czech Academy of Sciences of the Czech Republic, Rozvojová 269, 16500 Prague 6, Czech Republic; \\ ackerman@gli.cas.cz \\ ${ }^{2}$ Czech Geological Survey, Klárov 3, 11821 Prague 1, Czech Republic \\ ${ }^{3}$ Institute of Geochemistry, Mineralogy and Mineral Resources, Faculty of Science, Charles University, Albertov 6, 128 43 Prague 2, \\ Czech Republic \\ ${ }^{4}$ New Mexico Bureau of Geology and Mineral Resources, New Mexico Institute of Mining and Technology, 801 Leroy Pl, Socorro, USA \\ ${ }^{*}$ Corresponding author
}

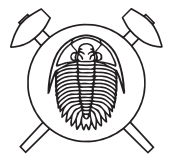

Four carbonatite bodies (Sukulu and Tororo - Uganda, Lemitar Mts. and Iron Hill - USA) from two intracontinental rift systems containing a prominent silicocarbonatite-carbonatite association were studied in detail in terms of petrography, major-/trace-element chemistry, and $\mathrm{Sr}-\mathrm{Nd}-\mathrm{C}-\mathrm{O}$ isotope systematics to provide constraints on their petrogenesis and mutual relationship. The Sukulu and Tororo carbonatites $(<30 \mathrm{Ma})$ within the East African Rift System are characterized by the wide range of $\mathrm{SiO}_{2}$ contents and presence of phlogopite \pm olivine and aegirine-augite $+\mathrm{K}$-feldspar, respectively. These different mineral parageneses correspond to the $\mathrm{Mg}-\mathrm{K}$-rich nature of the former and $\mathrm{Na}-\mathrm{Fe}-\mathrm{K}$-rich composition of the latter. Overall, these signatures can be best explained by progressive fractionation of parental carbonated silicate melts and liquid immiscibility documented by the chemical variation of clinopyroxene and the presence of silicate-carbonate pockets. However, at Tororo, this process was likely accompanied by assimilation of local crustal lithologies to account for its different $\mathrm{Sr}-\mathrm{Nd}$ isotopic signatures and Na-rich nature of carbonatites. Despite their spatial and temporal difference, the Lemitar Mts. and Iron Hill from the Cambro-Ordovician North American Rift resemble similar petrography and mineralogy as Sukulu and Tororo bodies, expressed by the presence of phlogopite and clinopyroxene $+\mathrm{K}$-feldspar. We present a general model explaining the origin of silicocarbonatite-carbonatite association involving segregation of silicate and carbonate melts from parental carbonated silicate melts through a process of liquid immiscibility. Subsequent distinct evolutionary paths are related to differences in $\mathrm{Si}-\mathrm{Na}-\mathrm{K}-\mathrm{Fe}-\mathrm{Mg}$ and $\mathrm{H}_{2} \mathrm{O}-\mathrm{F}$ contents, oxygen fugacity, and melt ascent efficiency, perhaps related to crustal assimilation. Therefore, we emphasize that relatively silica-rich carbonatites represent a crucial linkage between silicate and carbonate melts.

Keywords: carbonatite, silicate melt, rift system, $\mathrm{Sr}-\mathrm{Nd}$ isotopes, $\mathrm{C}-\mathrm{O}$ isotopes

Received: 3 December 2020; accepted: 30 March 2021; handling editor: V. Janoušek

The online version of this article (doi: 10.3190/jgeosci.320) contains supplementary electronic material.

\section{Introduction}

Carbonatites are magmatic rocks containing more than 50 vol. \% of primary carbonates (calcite, dolomite, or ankerite). Typically, carbonatites are enriched in many incompatible elements (e.g., REE, Nb, F), commonly forming substantial economic accumulations of these elements (e.g., Mitchell 2015; Fan et al. 2016). Carbonatitic melts span in age from Late Archean occurrences (Tupertalik, $\sim 3.0 \mathrm{Ga}$; Bizzarro et al. 2002) to active natrocarbonatite from Oldoinyo Lengai (Bell and Keller 1995). Their origin is usually attributed to either direct derivation from the upper mantle, fractional crystallization of parental silicate melts (Lee and Wyllie 1994; Veksler et al. 1998), or separation from mantle-derived carbonated silicate melts through liquid immiscibility (Gittins 1989; Mitchell 2005; Jones et al. 2013 and references therein). In either case, radiogenic $(\mathrm{Sr}-\mathrm{Nd}-\mathrm{Pb})$ and stable $(\mathrm{C}-\mathrm{O})$ isotopic systematics argue for predominantly convective mantle source of carbonatitic melts or their silicate melt precursors (e.g., Bell and Simonetti 2010; Ernst and Bell 2010; Jones et al. 2013), although there is a growing evidence that assimilation of crustal materials may play an important role in their evolution (Ackerman et al. 2017; Chandra et al. 2019; Lustrino et al. 2019, 2020).

In addition to carbonate minerals and abundant apatite, carbonatites also contain variable proportions of silicate minerals (e.g., phlogopite, clinopyroxene, amphibole, perovskite, olivine, monticellite) whose chemistry and texture can be used as important petro- 
genetic indicators (e.g., Viladkar 2000, 2017; Reguir et al. 2009, 2012; Lustrino et al. 2019). This leads to elevated whole-rock $\mathrm{SiO}_{2}$ contents (silica-rich carbonatite containing $>5 \mathrm{wt} . \% \mathrm{SiO}_{2}$ ), and ultimately silicocarbonatites containing $>20$ wt. \% $\mathrm{SiO}_{2}$ (Le Maitre 2002). Despite the observation that silica-rich carbonatites/ silicocarbonatites are quite common rock types that accompany many carbonatite occurrences worldwide (e.g., Ying et al. 2004; Gittins et al. 2005; Reguir et al. 2012; Ackerman et al. 2017; Viladkar 2017; see also GEOROC database - Sarbas et al. 2017 - for more examples), they represent an overlooked lithology that has not yet been studied in detail.

To improve our understanding of the petrogenesis of these rocks and their role in the evolution of carbonatitic melts, we present a detailed study of four carbonatite suites from continental rift settings: Cenozoic Sukulu and Tororo, located within the East African Rift System in Uganda, and two Ediacaran/early Paleozoic bodies of Lemitar Mts. and Iron Hill ( $\sim 50 \mathrm{Ma}$ and $\sim 580-540 \mathrm{Ma}$, respectively) from the rift systems in the western USA (Fig. 1a). These complexes contain abundant silica-rich carbonatites in a close association with a "pure" carbonatite end member and, therefore, can provide a direct link between these carbonatite types. We show that silica-rich carbonatites can represent a crucial linkage between silicate and carbonate melts.

\section{Samples and geological setting}

\subsection{Sukulu and Tororo carbonatites}

The Sukulu and Tororo carbonatites (calcite with only subordinate dolomite/ankerite type) within the East African Rift System (EARS) are located in southeastern Uganda and, together with the nearby Napak carbonatite-nephelinite complex (Simonetti and Bell 1994), are thought to be of a similar age $(<30 \mathrm{Ma}$; Nelson et al. 1988; Bell and Simonetti 1996). The material studied here was acquired from the Czech Geological Survey sample repository containing carbonatites collected during two Czechoslovak expeditions in the 1970's. Both occurrences consist of circular hills with a diameter of $\sim 4$ and $1 \mathrm{~km}$, respectively (Fig. 1b), rimmed by syenite, ijolite (plutonic rock dominated by clinopyroxene and nepheline), and melteigite (melanocratic variety of ijolite with 10-30 vol. \% nepheline) and surrounded by fenitized granitic gneisses (Reedman 1984).

The Sukulu carbonatite ( 24-26 Ma; Davies 1965; Bloomfield 1973) is represented by predominant calcite-dolomite carbonatite containing variable amounts of silicate minerals (olivine, phlogopite), magnetite, and apatite (Benkó et al. 2021). In contrast, the Tororo calcite carbonatite ( 16-32 Ma; Bell and Blenkinsop 1987) is characterized by the presence of clinopyroxene (aegirineaugite) and $\mathrm{K}$-feldspar as the principal silicate mineral phases (Benkó et al. 2021). Available Sr-Nd and noble gas $(\mathrm{He}-\mathrm{Ne})$ isotopic data suggest that the source of parental melts for both carbonatite bodies was a mixture of depleted and only slightly enriched mantle reservoirs (Bell and Blenkinsop 1987; Benkó et al. 2021). Detailed fluid inclusion studies on both complexes (Benkó et al. 2021) revealed the importance of late-stage hydrothermal circulation and common hydrothermal overprint of primary mineral phases.

\subsection{Lemitar Mts. and Iron Hill carbonatites}

The Lemitar Mts. carbonatite dikes (ankerite carbonatite and calcite carbonatite) crop out in the Lemitar Mts., which is an uplift in the Cenozoic Rio Grande Rift ( $\sim 30 \mathrm{Ma}$ to present), New Mexico, USA (Fig. 1c). During the Cambrian-Ordovician regional magmatic event at $\sim 450$ Ma (McLemore 1982), dike swarms of (silico-) carbonatites were emplaced within granite, diorite, and gabbro (McLemore and Moderski 1990). The magmatic rocks produced during this rifting event, i.e., carbonatites, syenites, monzonites and mafic dikes, with associated K-metasomatism (i.e., fenites, episyenites) and $\mathrm{Th}-\mathrm{REE} \pm \mathrm{U}$ mineral deposits, are found throughout southern Colorado and New Mexico (McMillan and McLemore 2004).

The carbonatite dikes range in width from a few centimeters to more than a meter and can be recognized over a distance exceeding 600 meters (McLemore 1987; McLemore and Moderski 1990). We collected several dikes intruding the central part (diorite/gabbro) of the Lemitar Mts. and one dike (UC09) in the southern part of Lemitar Mts., where carbonatites intruded into metasediments (Fig. 2a-b; see Electronic Supplementary Material, ESM 1 for GPS co-ordinates). The carbonatite dikes of variable orientations are well-exposed in gullies, where the ephemeral streams removed weathering cover.

The Iron Hill carbonatite complex (Colorado, USA; Fig. 1d) consists of carbonatite accompanied by syenite, pyroxenite, ijolite, and uncompahgrite (melilite-bearing plutonic rock) intruding into the Proterozoic granite and metamorphic basement (e.g., Nash 1972 and references

Fig. 1 Location of analyzed samples. a - Location of Cambro-Ordovician North-American Rift (after McMillan and McLemore 2004) and East-African Rift System. b - Geological sketch map of Sukulu and Tororo complexes (simplified after Raja and Vise 1973). c - Geological sketch map of Lemitar carbonatites (simplified after McLemore 1982). d - Geological sketch map of Iron Hill (simplified after Olson et al. 1977). 

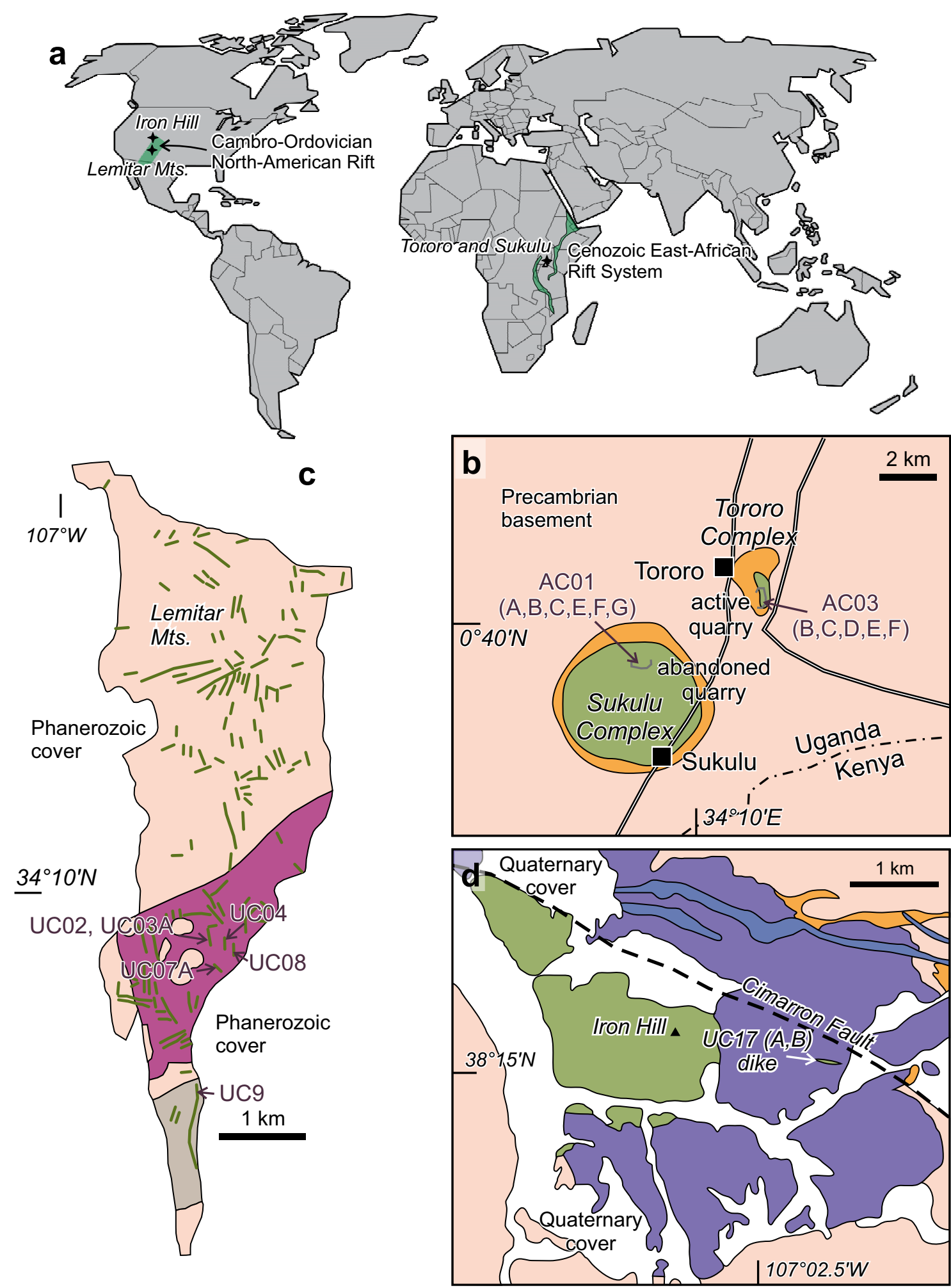

Carbonatite-alkaline complexes

\section{Basement rocks}

carbonatite

ijolite+melteigite nepheline syenite

(meta-)granite

diorite/gabbro

ijolite, pyroxenite, uncompahgrite late diabase dikes metasediments 

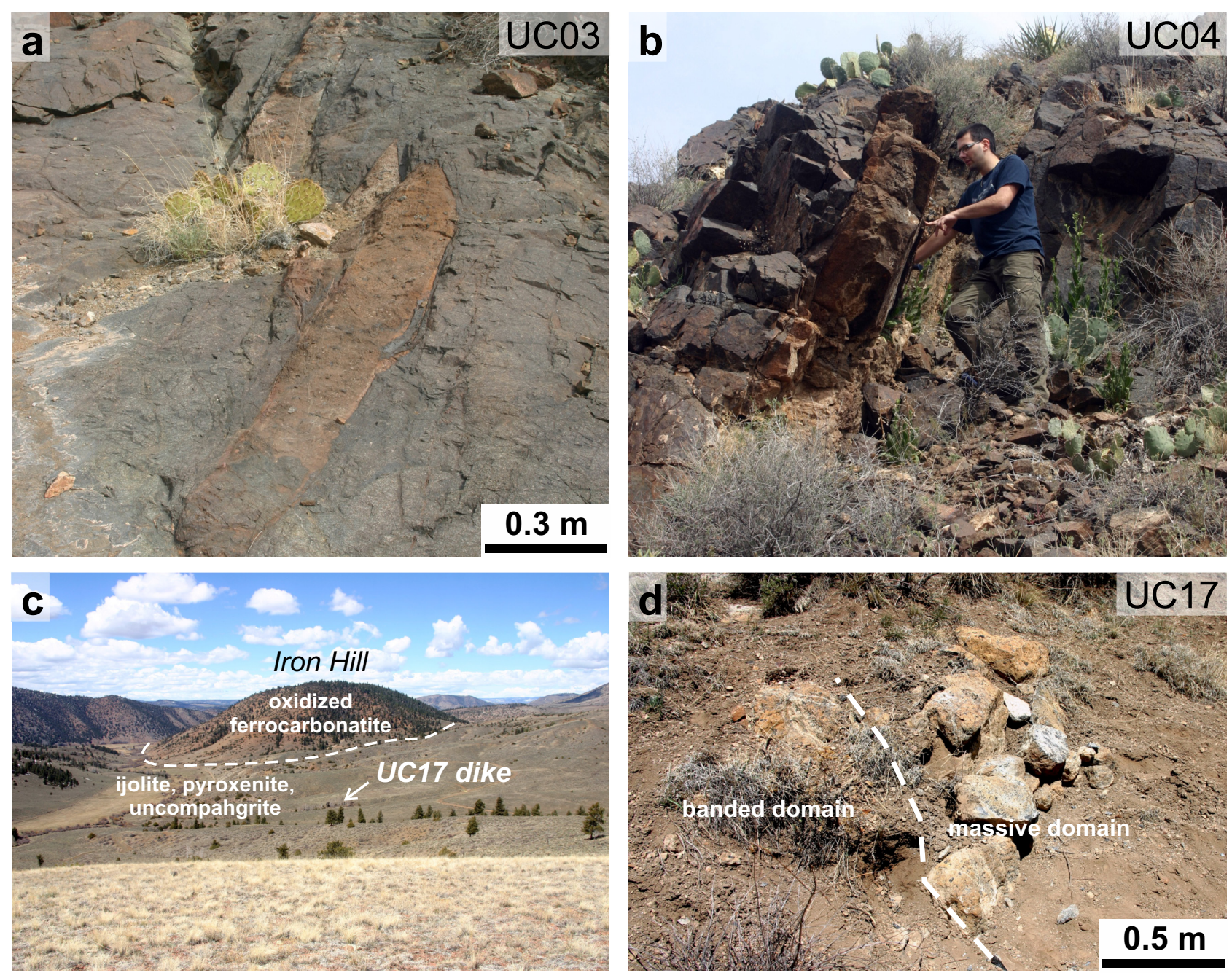

Fig. 2 Field photos of the US localities. a - Carbonatite dike UC03 penetrating Polvadera diorite (Lemitar Mts.). b - Phlogopite-rich carbonatite dike UC04 cutting the Polvadera diorite (Lemitar Mts.). c - Iron Hill general view. d - Remnants of composite dike UC17 (Iron Hill Complex).

therein). According to the wider geological situation, Iron Hill is interpreted to be emplaced during the same Cambrian-Ordovician rifting-related magmatism as the Lemitar Mts. carbonatites (McMillan and McLemore 2004), despite the published geochronological data suggesting rather Ediacaran-Cambrian age (K-Ar on biotite from $543 \pm 8$ to $574 \pm 9 \mathrm{Ma}$; $\mathrm{Rb}-\mathrm{Sr}$ on biotite and wholerock $579 \pm 10 \mathrm{Ma}$; Olson et al. 1977). Nash (1972) suggested that carbonatitic and silicate magmas were formed in two separate events during the late-stage crystallization of parental silicate magma. Several carbonatite types have been found at the Iron Hill, but ankerite-dolomite carbonatite predominates. A rather unusual rock at the Iron Hill is a silicocarbonatite containing high proportions of silicate minerals (Nash 1972). To provide more details on this unusual rock type and its petrogenesis, we sampled a composite dyke composed of ankerite carbonatite in the core (UC17A) and banded ankerite silicocarbonatite (UC17B) in the outer part (see ESM 1 for GPS co-ordinates). The composite dike penetrates the complex of ijolites and carbonatites surrounding the intrinsic Iron Hill ferro-carbonatite plug (Fig. 2c). It is oriented radially from the central plug and emplaced close to the Cimarron Fault. The massive domain in the dike central part is rimmed by a banded domain, with bands enriched in silicate minerals parallel to the dike walls (Fig. 2d).

\section{Analytical methods}

After a preliminary examination using an optical microscope, carbonatitic rocks were studied in detail using a FEG-SEM Tescan Mira 3GMU equipped with an X-Max 20 EDX detector, housed at the Czech Geological Survey (CGS). Mineral chemistry analyses were conducted with an accelerating voltage of $15 \mathrm{kV}$, beam current of $3 \mathrm{nA}$, working distance $15 \mathrm{~mm}$, and counting time was set to $15 \mathrm{~s}$. A combination of natural and synthetic standards was used for calibration. Analyses 
were processed by the AZtec software (Oxford Instruments). The method of Vieten and Hamm (1978), which balances the deficiency of oxygen atoms corresponding to 4 cations (with all iron as $\mathrm{Fe}^{2+}$ ), was used to calculate $\mathrm{Fe}^{3+}$ content in clinopyroxene. Calculation of crystal-chemical formulae of feldspar was based on 8 oxygens. In the case of biotite, atomic proportion of $\mathrm{Mg}$ vs. $\left(\mathrm{Mg}+\mathrm{Fe}_{\mathrm{tot}}\right)$ was used only.

The whole-rock major-element concentrations were determined at the CGS using conventional wet chemistry involving gravimetry, titration, flame photometry and AAS (Dempírová et al. 2010), whereas trace-element contents were determined using an Agilent 7900x ICPMS. The precision of the analyses for both methods was always better than $5 \%$, and the accuracy of the analytical protocols was monitored through replicate analyses of reference materials COQ-1 (carbonatite, USGS) and BCR-2 (basalt USGS).

$\mathrm{The} \mathrm{Sr}-\mathrm{Nd}$ isotopic compositions were determined following the methods described elsewhere (e.g., Ackerman et al. 2020). In brief, $\sim 100 \mathrm{mg}$ of sample powder was dissolved in a mixture of $4 \mathrm{ml} 14 \mathrm{M} \mathrm{HNO}_{3}$ and $1 \mathrm{ml} 23 \mathrm{M} \mathrm{HF}$ on a hot plate at $140^{\circ} \mathrm{C}$ for at least 48 hours. Thereafter, $\mathrm{Sr}-\mathrm{Nd}$ isolation from the matrix was achieved by ion-exchange chromatography using the combination of Sr spec, TRU spec, and LN spec resins (Triskem Intl.) utilizing the column chemistry protocol described in Pin et al. (2014). The Sr-Nd isotopic compositions were determined using a Triton Plus thermal ionization mass spectrometers (Thermo) at the Institute of Geology of the Czech Academy of Sciences (IG CAS) and CGS, respectively. Strontium isotopic compositions were analyzed using either the W filaments with $\mathrm{Ta}_{2} \mathrm{O}_{5}$ activator (IG CAS) or Ta filaments (CGS) and ${ }^{88} \mathrm{Sr} /{ }^{26} \mathrm{Sr}$ of 8.3752 for mass bias correction. The $\mathrm{Nd}$ isotopic compositions were measured using a double-filament Re configuration at both labs and ${ }^{146} \mathrm{Nd} /{ }^{144} \mathrm{Nd}$ of 0.7219 for mass bias correction. The external reproducibility of the analyses was monitored through the long-term analyses of NIST SRM 987 (Sr) and JNdi-1 (Nd) solutions. At the IG CAS lab, they gave ${ }^{87} \mathrm{Sr} /{ }^{86} \mathrm{Sr}$ of $0.710249 \pm 5(2 \mathrm{SD}, \mathrm{n}=44)$ and ${ }^{143} \mathrm{Nd} /{ }^{144} \mathrm{Nd}$ of $0.512099 \pm 6(2 \mathrm{SD}, \mathrm{n}=26)$, respectively, whereas the CGS lab yielded values of ${ }^{87} \mathrm{Sr} /{ }^{86} \mathrm{Sr}$ of $0.710262 \pm 6$ $(2 \mathrm{SD}, \mathrm{n}=12)$ and ${ }^{143} \mathrm{Nd} /{ }^{144} \mathrm{Nd}$ of $0.512096 \pm 7(2 \mathrm{SD}$, $\mathrm{n}=12)$, respectively.

Stable $\mathrm{C}-\mathrm{O}$ isotopic compositions were determined following the decomposition procedure of McCrea (1950) and employing a Delta $V$ Advantage isotope ratio mass spectrometer housed at the CGS. The results are reported in conventional $\delta$ notation relative to V-SMOW for oxygen and V-PDB for carbon.

Data handling and plotting were performed using GCDkit software (Janoušek et al. 2006).

\section{Petrography, mineralogy, and mineral chemistry}

\subsection{Sukulu and Tororo carbonatite and carbonatitic pyroxenite}

Despite a close geographical relationship between Tororo and Sukulu complexes (just $2 \mathrm{~km}$ apart), the samples from the two bodies display significant differences. Sövites from both localities are dominated by calcite (in Sukulu with up to 2.0 wt. \% $\mathrm{MgO}$ and 1.4 wt. \% $\mathrm{SrO}$, and in Tororo with up to 0.15 wt. $\% \mathrm{MgO}$ and $1.0 \mathrm{wt}$. \% $\mathrm{SrO}$ ) prevailing over dolomite (highest dolomite content over 20 vol. \% in Sukulu AC01F carbonatite). They contain up to $\sim 15$ vol. \% (ESM 1) of oval apatite grains up to $1 \mathrm{~mm}$ across (Fig. 3a-b).

In the Sukulu carbonatites, the main silicate phase is phlogopite, but sample AC01C previously studied by Benkó et al. (2021) also contains abundant ( $\sim 7$ vol. \%) olivine phenocrysts (ESM 1; Fig. 3c) with $\mathrm{Fo}_{86-88}$. The olivine phenocrysts are commonly $5 \mathrm{~mm}$ across but may reach up to $1 \mathrm{~cm}$ and display only weak and very thin weathering-related alteration along crystal margins and cracks. Olivine tends to be coated by small phlogopite grains (Fig. 3c), but no reaction can be seen even in direct contact with carbonate; no monticellite rim was observed. Phlogopite flakes are $0.2-1 \mathrm{~mm}$ large, with well visible cleavage without any alteration signs. Despite significant optical zoning of phlogopite, only minor compositional variation was observed (Fig. 4a), with slightly more ferrous rims $\left(\mathrm{Mg} \#=85 ; \mathrm{Mg} \#=100 \times \mathrm{Mg}\left[\mathrm{Mg}+\mathrm{Fe}_{\text {tot }}\right]\right)$ compared to cores $(\mathrm{Mg} \#=90$; ESM 2). Magnetite is present, except the sample AC01F, in the form of up to $3 \mathrm{~mm}$ large grains.

By contrast, the Tororo carbonatites do not contain phlogopite, and the silicate phase is represented mainly by abundant (up to 26 vol. \%; ESM 1) greenish idiomorphic clinopyroxene (Fig. 3d-e), with the composition of aegirine-augite (Ae 45-65 mol. \%; Fig. 5; ESM 3). Aegirine-augite in the form of $0.5-1 \mathrm{~mm}$, but occasionally over $3 \mathrm{~mm}$ long idiomorphic crystals occurs either dispersed through the matrix (Fig. 3d) or in clusters with apatite and subordinate K-feldspar (up to 6.5 vol. \%; ESM 1, Fig. 3e) of sanidine composition (Or 89-93 mol. \%; ESM 4). These clusters with the predominance of non-carbonate minerals are delimited from surrounding carbonatite by irregular boundaries. Besides rather large and irregular clusters, the Tororo carbonatites also contain silicate-carbonate pockets of a smaller size and sharp outlines (Fig. 3f) with the mineral assemblage of aegirine-augite (Ae 78-87 mol. \%) prevailing over quartz, apatite, and pyrrhotite. Aegirine-augite in the pockets differs from that in the matrix by lower $\mathrm{CaO}$ content (Fig. 5). The carbonatitic 

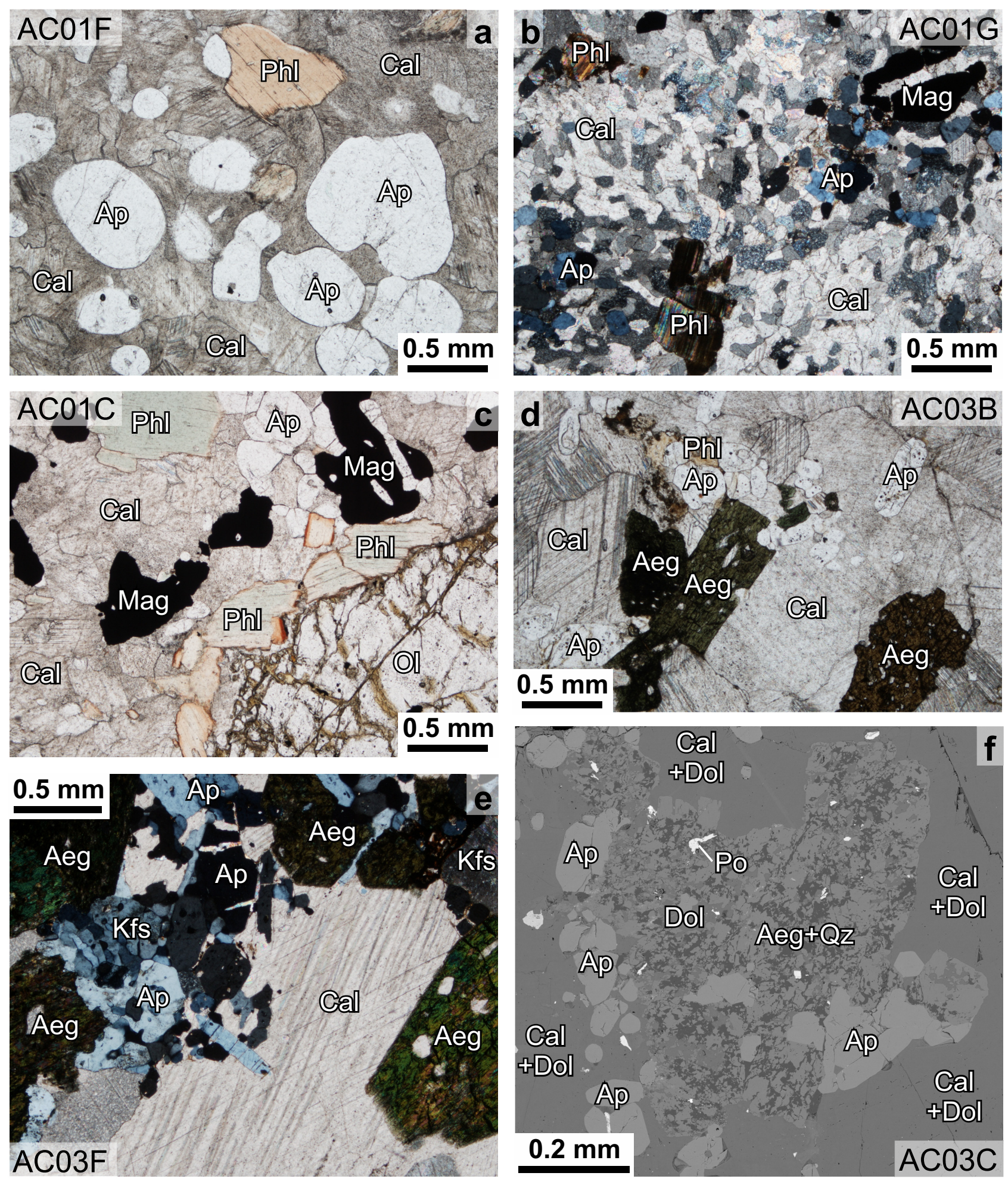

Fig. 3 Photomicrographs of the Uganda carbonatites. a - Coarse-grained facies of Phl-Ap-rich Sukulu carbonatite (sample AC01F, plane-polarized light - PPL). b - Fine-grained facies of Phl-Ap-rich Sukulu carbonatite (sample AC01G, cross-polarized light - XPL). c - Olivine-bearing Phl-Ap-rich carbonatite at Sukulu (sample AC01C, PPL). d - "Dry" assemblage of Tororo carbonatite, scarce Phl among Aeg, Ap and Cal crystals (sample AC03B, PPL). e - Sharp boundary between silicate- and carbonate-dominated domains in the Tororo sample AC03F (XPL). f - Silicatecarbonate pocket in Tororo carbonatite (sample AC03C, back-scattered electron image - BSE). Aeg - aegirine, Ap - apatite, Cal - calcite, Dol - dolomite, Kfs - K-feldspar, Ol - olivine, Phl - phlogopite, Qz - quartz. 


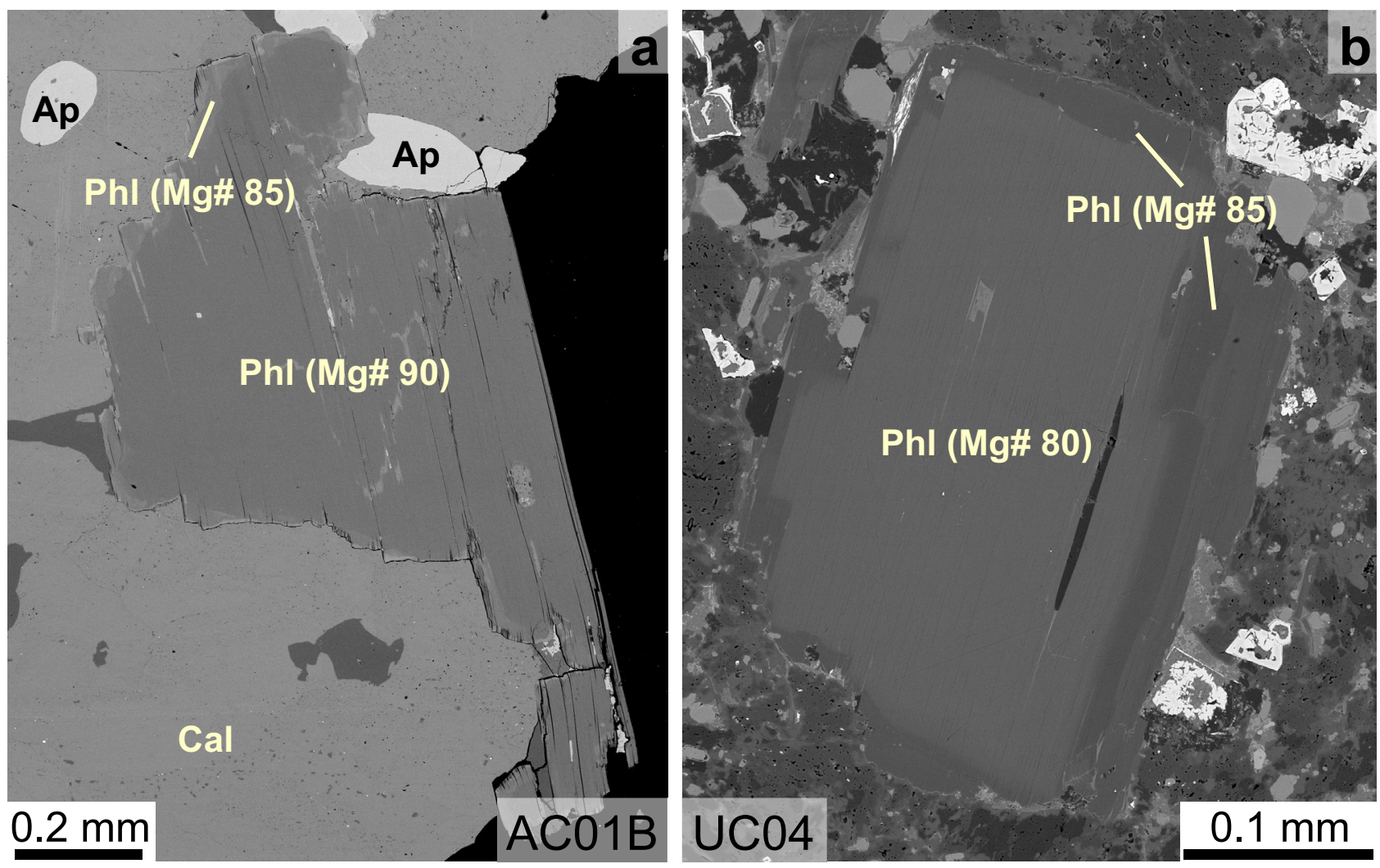

Fig. 4 Back-scattered electron images of phlogopite from Sukulu (a) and Lemitar (b) carbonatites together with their calculated Mg\# values. $\mathrm{Ap}$ - apatite, $\mathrm{Cal}$ - calcite, $\mathrm{Phl}$ - phlogopite.

pyroxenite $(\mathrm{AC} 03 \mathrm{~F})$ is essentially composed of clinopyroxene and carbonate (sum up 71 vol. \%). At both EARS localities, the accessory phases are represented by heterogeneously distributed pyrochlore grains up to $0.1 \mathrm{~mm}$ in size. In BSE (back-scattered electron) images, the pyrochlores display a larger homogeneous magmatic core but thin hydrothermally recrystallized rim.

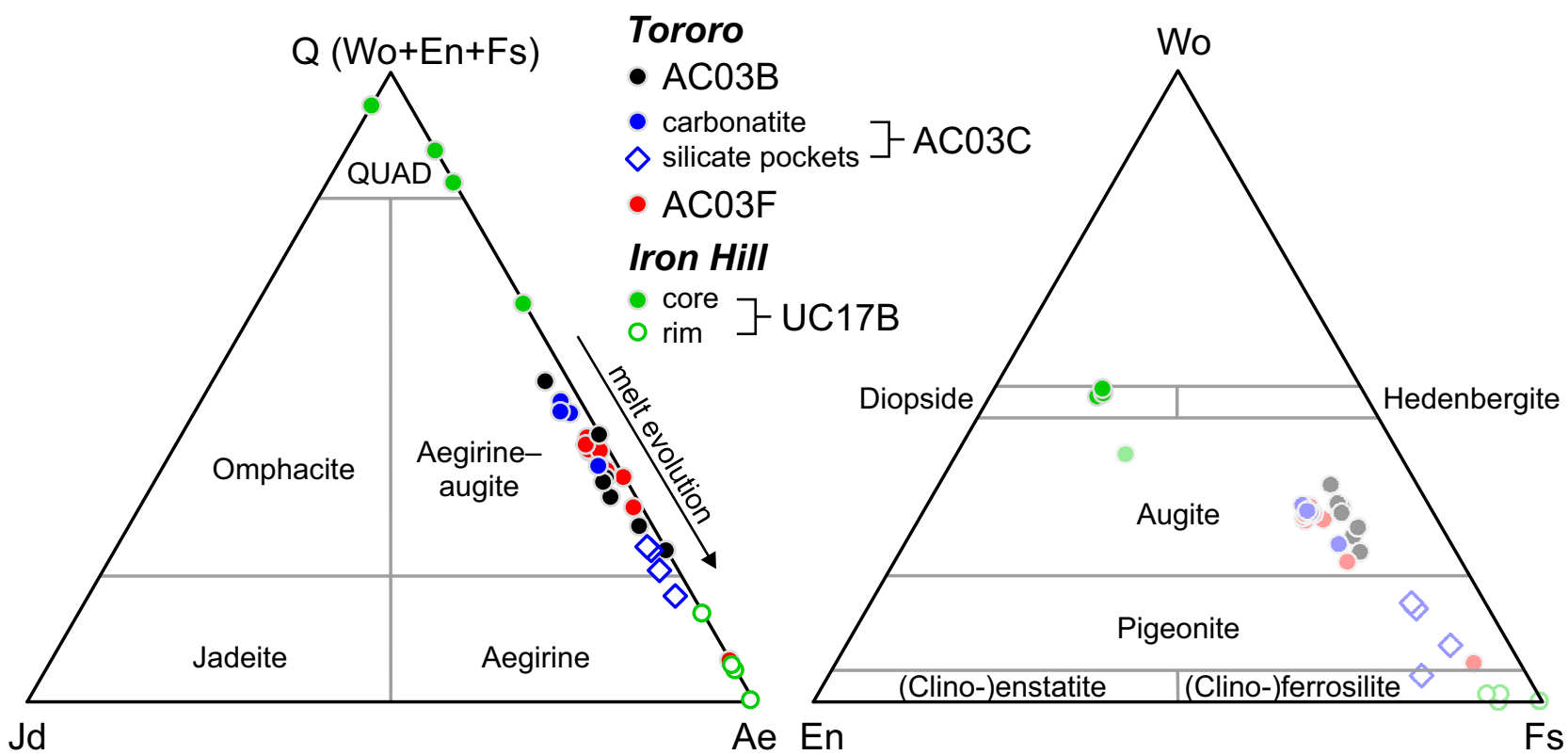

Fig. 5 Composition of the analysed clinopyroxenes in classification diagrams (Morimoto 1988). Non-quad pyroxenes are plotted as semitransparent in quadrilateral diagram to display the general trend of decreasing $\mathrm{Ca}$ and $\mathrm{Mg} / \mathrm{Fe}$. 

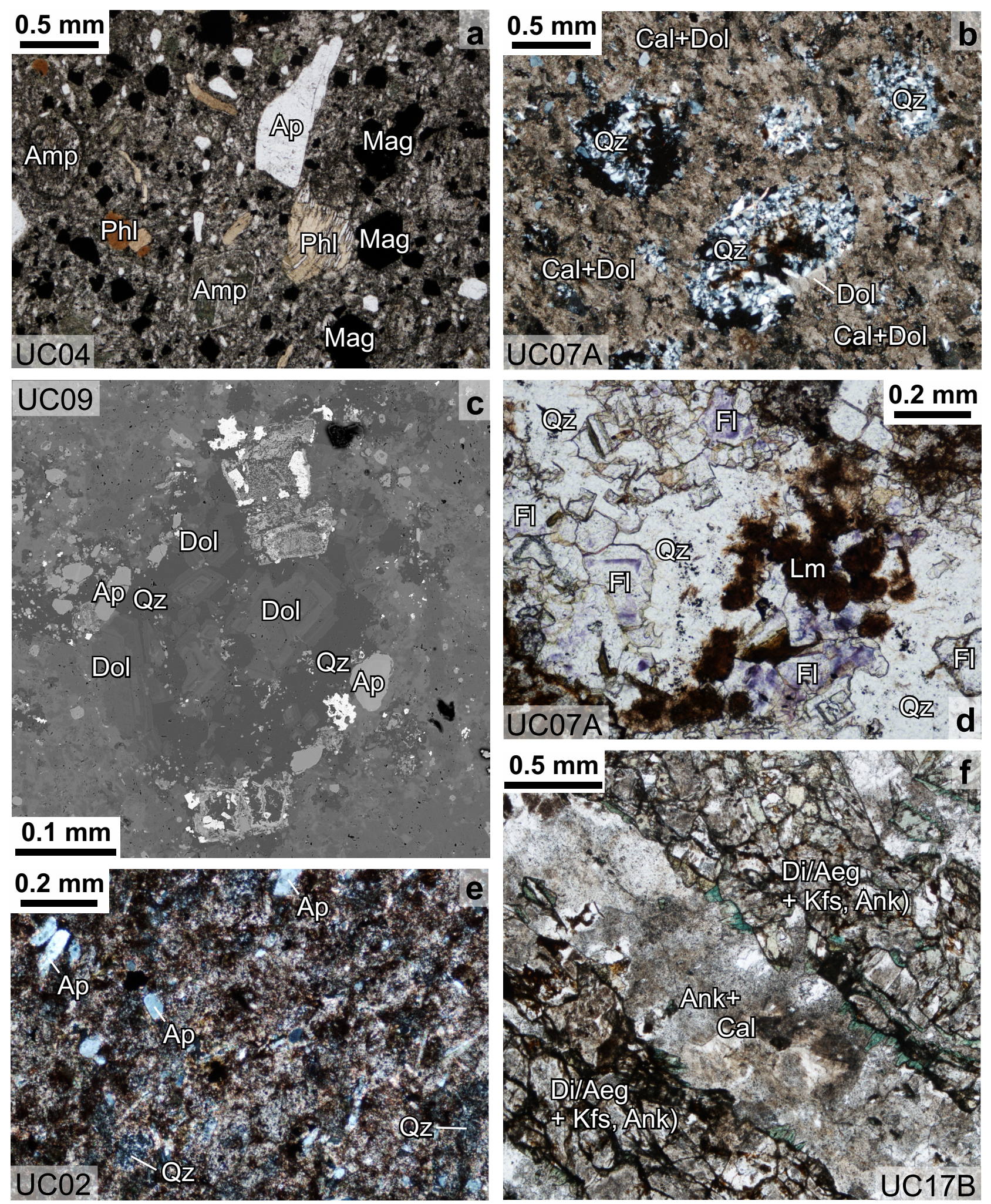

Fig. 6 Photomicrographs of Uganda, Lemitar and Iron Hill carbonatites. a - Phenocrysts of primary silicates (Phl and pseudomorphosed Amp), Mag and Ap in UC04 silicocarbonatite (PPL). b - Qz-rich ocelli in UC07A silicocarbonatite (XPL). c - BSE image of Qz-Dol ocellus in UC09 silicocarbonatite. d - Detail on post-magmatic fill of amygdale in UC07A silicocarbonatite (PPL). e - Pervasively silicified carbonatite UC02 (XPL). f - Alternation of silicate and carbonate bands in the marginal part of the UC17 composite dike (sample UC17B, PPL). Aeg - aegirine, Amp - pseudomorphosed amphibole, Aeg - aegirine, Amp - amphibole, Ank - Ankerite, Ap - Apatite, Cal - calcite, Di - diopside, Dol - dolomite, Fl - fluorite, Kfs - K-feldspar, Lm - limonite (s.1.), Mag - magnetite, Qz - quartz. 


\subsection{Lemitar Mts. and Iron Hill carbonatite and silicocarbonatite}

The Lemitar Mts. dikes display different features of silicate/carbonate coexistence. Primary silica-rich carbonatite texture can be seen in the sample UC04, with phlogopite ( 8 vol. \%; ESM 1), apatite, and magnetite (micro)phenocrysts (Fig. 6a). The phenocrysts display moderately preferred (dike-wall parallel) orientation, and phlogopite also has signs of emplacement-related deformation. These features suggest a primary origin and the presence of these minerals before emplacement of the dike. Phlogopite shows reverse chemical zoning (Mg\# of 80 in the core versus $\mathrm{Mg} \#$ of 85 in the rim: Fig. $4 b)$ and $\mathrm{Mg}-\mathrm{Al}-\mathrm{Fe}^{3+}$ contents similar to other micas from carbonatites given elsewhere (Reguir et al. 2009). In other samples (UC07A, UC09), silica excess is present in dolomite-quartz-apatite ocelli (Fig. 6b-c) with somewhat transitional boundaries and the surrounding groundmass is dominated by calcite and dolomite of primary character. However, the rocks also contain voids/vesicles filled with secondary quartz/chalcedonyfluorite-limonite association (Fig. 6d) and a network of quartz/chalcedony pervasively replacing original carbonatitic groundmass pointing to late-stage silicification of these rocks (Fig. 6e). Contrary to somewhat transitional boundaries in dolomite-quartz-apatite ocelli, the secondary quartz/chalcedony-fluorite-limonite amygdales are delimited from the matrix by sharp boundaries.

The Iron Hill samples UC17A and UC17B represent two domains of a single dike associated with the main plug of ankerite carbonatite. The central part (UC17A) is represented by a calcite + ankerite carbonatite replaced by siderite free of silicate phases and with only a few grains of magnetite. Banded silicocarbonatite UC17B representing the marginal part of the dike consists of carbonate (predominantly calcite with subordinate ankerite; ESM 1) layers that alternate with clinopyroxene-dominated silicate ones (Fig. 6f). The clinopyroxene in these layers is compositionally zoned, with diopside or aegirine-augite cores rimmed by aegirine rims (Fig. 5) and is associated with K-feldspar (sanidine, ESM 4) and ankerite-siderite. Ankerite is locally corroded by barite, and aegirine is sometimes replaced by skeletal $\mathrm{Nb}$-rutile.

Pyrochlore is abundant and it is present in variable quantities in the Lemitar Mts. and Iron Hill (silico)carbonatites. In many cases, the pyrochlore displays sieved or skeletal texture suggesting a significant role of hydrothermal overprint.

\section{Whole-rock major-, minor- and trace- element compositions}

The examined carbonatitic rocks, including those analyzed by Benkó et al. (2021), exhibit a wide range of $\mathrm{SiO}_{2}$ con- tents from $<0.1$ to $25.5 \mathrm{wt} \%$ (ESM 5). However, only one sample (UC17B from Iron Hill) having more than $20 \mathrm{wt} . \%$ $\mathrm{SiO}_{2}$ can be classified as silicocarbonatite, while the sample AC03F (Tororo) with the highest $\mathrm{SiO}_{2}$ content has a modal composition of carbonatitic pyroxenite ( $\sim 35$ vol. $\%$ carbonates; $\mathrm{ESM} 1)$. In terms of $\mathrm{MgO}-\mathrm{CaO}-\mathrm{FeO}+\mathrm{Fe}_{2} \mathrm{O}_{3}+\mathrm{MnO}$ variation (Fig. 7a), the Sukulu and Tororo carbonatites from EARS have predominantly a composition of calcio-carbonatite, which is consistent with petrography. In contrast, those from the Lemitar Mts. yield a composition of calcio- and magnesio-carbonatite, and the Iron Hill (silico)carbonatites can be classified as ferro-carbonatites (Fig. 7b). The silicarich $\left(>5\right.$ wt. $\left.\% \mathrm{SiO}_{2}\right)$ carbonatites are typically enriched in $\mathrm{MgO}, \mathrm{FeO}$ and $\mathrm{Al}_{2} \mathrm{O}_{3}$, with minor amounts of $\mathrm{TiO}_{2}$ (up to 0.79 wt. \%) reflecting more significant proportions of $\mathrm{Fe}-$ Mg-silicates (e.g., phlogopite, clinopyroxene; see above) and K-feldspar compared to pure carbonatites (ESM 5). The silica-rich carbonatites from Tororo are rich in $\mathrm{Na}_{2} \mathrm{O}$ (1.4-3.4 wt. \%) due to the presence of aegirine-augite. Silicocarbonatite sample UC17B from the Iron Hill shows an extreme enrichment in $\mathrm{TiO}_{2}(6.7 \mathrm{wt}$ \% $\%$ ) due to the common presence of secondary rutile. Overall, all carbonatites show high $\mathrm{P}_{2} \mathrm{O}_{5}$ (up to 6.3 wt. \%) that are positively correlated with $\mathrm{F}$ contents (not shown) due to the presence of fluorapatite (Fig. 3). Carbonatites from Lemitar (UC02, UC03A, UC08) that underwent late-stage silicification are characterized by high $\mathrm{SiO}_{2}$ content up to 17 wt. \%, commonly paralleled by high $\mathrm{F}$ contents (up to 9 wt. \%) due to the fluorite presence without concomitant enrichment in $\mathrm{Al}_{2} \mathrm{O}_{3}$ (ESM 5).

With the exception of the Iron Hill carbonatites that exhibit a specific convex-upward REE pattern with $\mathrm{La}_{\mathrm{N}} /$ $\mathrm{Sm}_{\mathrm{N}}<1$, the other rock types share mutually similar, LREE-enriched distributions (Fig. 7b). The late-stage SiF-enrichment in Lemitar Mts. carbonatites is expressed by higher HREE contents $\left(\mathrm{La}_{\mathrm{N}} / \mathrm{Yb}_{\mathrm{N}}=10-19\right.$ versus $40-87$ in the rest of the suite). Besides, the analyzed carbonatites show an extreme variation in $\mathrm{Nb}-\mathrm{Ta}$ and $\mathrm{Zr}-\mathrm{Hf}$ contents, over three orders of magnitude for Th and U (Fig. 7c), and the Sukulu and Tororo samples are enriched in $\mathrm{Sr}$ in comparison to the Lemitar Mts. and the Iron Hill carbonatites $\left(\mathrm{Sr}_{\mathrm{N}} / \mathrm{Nd}_{\mathrm{N}}=0.9-4.6\right.$ vs. $\left.0.1-0.5\right)$. These features reflect late magmatic and/or hydrothermal/carbohydrothermal overprint and mineralization that often modify elemental budgets and distribution of many trace elements (e.g., V, $\mathrm{Ba}, \mathrm{Sr}, \mathrm{REE}, \mathrm{U}, \mathrm{Th}, \mathrm{Nb}$ ). This can be, for example, due to alteration of U-Th-rich pyrochlore, and formation of vanadinite (e.g., Magna et al. 2020), but also barite, celestine, Sr- or REE-carbonates and other low-temperature phases.

\section{Sr-Nd-C-O isotopic systematics}

Overall, the EARS carbonatites are predominantly characterized by depleted mantle-like $\mathrm{Sr}-\mathrm{Nd}$ isotopic 

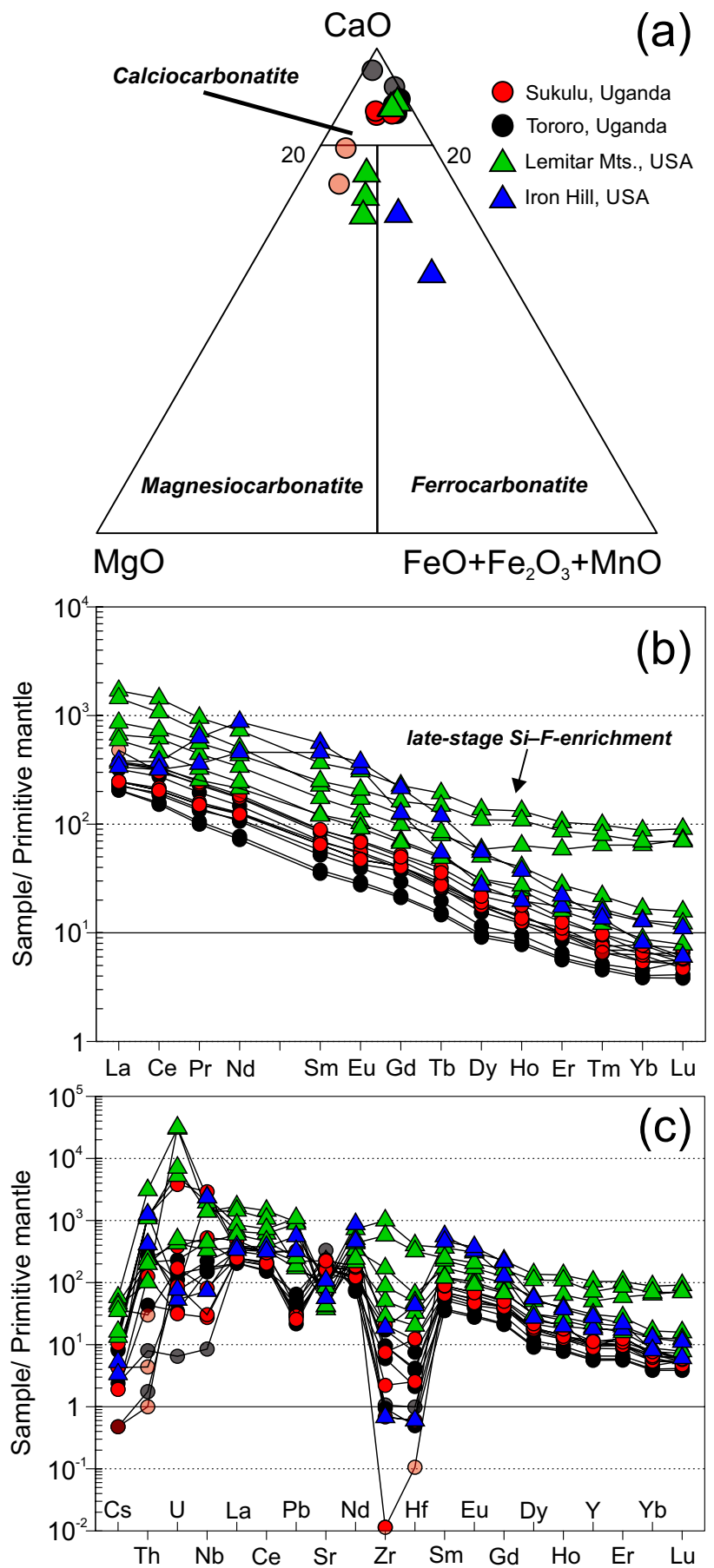

Fig. 7a - Classification of carbonatitic rocks using $\mathrm{MgO}-\mathrm{CaO}-\mathrm{FeO}$ $+\mathrm{Fe}_{2} \mathrm{O}_{3}+\mathrm{MnO}$ ternary diagram (Woolley 1982; Le Maitre 2002). b - REE multielement plot for the studied rocks normalized to primitive mantle values (McDonough and Sun 1995). c - Trace-element patterns normalized to primitive mantle values (McDonough and Sun 1995). In both latter diagrams, the previously studied carbonatites from Tororo and Sukulu complexes (Benkó et al. 2021) are also included (semitransparent).

signatures with positive $\varepsilon \mathrm{Nd}_{(\mathrm{i})}$ values of +3.3 to +3.6 (Sukulu) and +1.4 to +2.1 (Tororo; including carbonatitic pyroxenite $\mathrm{AC} 03 \mathrm{~F}$ ), and ${ }^{87} \mathrm{Sr} /{ }^{86} \mathrm{Sr}_{(\mathrm{i})}<0.704$ (Fig. 8a;
ESM 6), without any relationship to silica enrichment. This is paralleled by the predominantly mantle-like $\mathrm{C}-\mathrm{O}$ systematics of these rocks. Still, we note that two Tororo samples are displaced towards a lower $\delta^{13} \mathrm{C}(\mathrm{AC} 01 \mathrm{~F})$ and higher $\delta^{18} \mathrm{O}\left(\mathrm{AC} 01 \mathrm{G}\right.$ with more radiogenic ${ }^{87} \mathrm{Sr} /{ }^{86} \mathrm{Sr}$ ) compared to the rest of the suite (Fig. 8b), features that might be related to hydrothermal influence and low-T fluid circulation (Benkó et al. 2021).

On the other hand, the Lemitar Mts. carbonatites exhibit decoupled $\mathrm{Sr}-\mathrm{Nd}$ isotopic signatures with highly variable ${ }^{87} \mathrm{Sr} /{ }^{86} \mathrm{Sr}_{(\mathrm{i})}$ values $(0.704-0.710)$ at rather singular $\varepsilon \mathrm{Nd}_{(\mathrm{i})}$ of $\sim+3$ (Fig. 8a). Only the silicified carbonatite $\mathrm{UCO} 2$ is displaced off this general array by having $\varepsilon \mathrm{Nd}_{(\mathrm{i})}$ of +0.2 . Similarly, the silicocarbonatite UC17B from the Iron Hill has a significantly lower $\varepsilon \mathrm{Nd}_{(\mathrm{i})}$ of +0.7 compared to carbonatite $\mathrm{UC} 17 \mathrm{~A}\left(\varepsilon \mathrm{Nd}_{(\mathrm{i})}=+2.9\right)$ in spite of similar ${ }^{87} \mathrm{Sr} /{ }^{86} \mathrm{Sr}_{(\mathrm{i})}$ of $\sim 0.7035$ (Fig. 8a).

\section{Discussion}

As shown above, many carbonatites from the studied localities are unambiguously enriched in $\mathrm{SiO}_{2}$. These can easily be distinguished from silicified carbonatites from the Lemitar Mts. that contain dispersed secondary quartz grains within carbonatite matrix and that likely originated by late-stage overprint by $\mathrm{Si}-\mathrm{Ba}-(\mathrm{F})$ hydrothermal solutions (Fig. 6d-e). The silica-rich carbonatites and silicocarbonatite contain significant proportions of silicate phases (e.g., clinopyroxene, mica), and their texture argues for a close petrogenetic relationship to the associated carbonatites.

Two nearby carbonatite bodies, Sukulu and Tororo (EARS), contain a carbonatitic suite with a wide range of $\mathrm{SiO}_{2}$ contents, which can provide unique constraints on the carbonatitic melt evolution and a possible relationship to silicate melts. At Sukulu, silica-rich carbonatites contain variable amounts of phlogopite ( \pm olivine), whereas at Tororo, aegirine-augite and K-feldspar are the predominant silicate phases (Fig. 3; see also Benkó et al. 2021). Furthermore, Tororo samples are displaced in the $\mathrm{Sr}-\mathrm{Nd}$ space (Figs 8a, 9a) from Sukulu by having somewhat higher ${ }^{87} \mathrm{Sr} /{ }^{86} \mathrm{Sr}_{(\mathrm{i})}$ and less radiogenic $\varepsilon \mathrm{Nd}_{(\mathrm{i})}$ values, but in both cases still within the range typical of depleted mantle-derived carbonatites. Overall, such $\mathrm{Sr}-\mathrm{Nd}$ isotopic signatures cannot be easily connected to late-stage hydrothermal alteration by Sr-rich fluids as they would produce a horizontal array. Hence, they must be connected with either contrasting mantle sources or different evolution of their parental alkaline and $\mathrm{CO}_{2}$ rich silicate melts. The former scenario is considered unlikely, considering a similar association of silica-rich carbonatites, carbonatites, and alkaline silicate rocks (ijolite-melteigite-nepheline syenite) at both localities 
of similar age (Davies 1965; Bloomfield 1973; Bell and Blenkinsop 1987). Therefore, we favor the latter scenario that can be further expanded into a model as follows.

Progressive fractional crystallization (olivine, clinopyroxene, nepheline $\pm \mathrm{Fe}-\mathrm{Ti}$ oxide) of parental, water-rich and carbonated alkali silicate melt (with the assumed composition of olivine nephelinite from the north-easterly Napak nephelinite-carbonatite complex; Simonetti and Bell 1994) during its ascent leads to the formation of Sukulu phlogopitebearing silica-rich carbonatites. The final evolutionary stage represents "pure" carbonatites (Fig. 10) that originated through the liquid immiscibility (e.g., Kjarsgaard 1989; Lee and Willey 1998; Halama et al. 2005; Brooker and Kjarsgaard 2011). At Tororo, however, this parental silicate melt must have undergone contamination by a local crust to account for a more radiogenic ${ }^{87} \mathrm{Sr} /{ }^{86} \mathrm{Sr}_{(\mathrm{i})}$ signature, paralleled by lower $\varepsilon \mathrm{Nd}_{(\mathrm{i})}$ values (Fig. 8a). The Sukulu and Tororo bodies intruded into Archean basement rocks (gneiss, granulite), forming the eastern extension of the Congo Craton (so-called Gneissic Granulite Complex; Leggo 1974; Link et al. 2010). Mixing between parental carbonated melt and average basement rock (best estimated from local fluvial sediments; Padoan et al. 2011)

Fig. $8 \mathrm{Sr}-\mathrm{Nd}-\mathrm{C}-\mathrm{O}$ isotopic systematics of the studied carbonatites. a - Initial $\varepsilon N d v s .{ }^{87} \mathrm{Sr} /{ }^{86} \mathrm{Sr}$ diagram showing also the position of present-day HIMU, EMI and EMII reservoirs (Harte 1988). b - Plot of oxygen and carbon stable isotope compositions. A dashed field corresponds to the mantle values of Kyser (1990), while the primary carbonatite field is from Ray and Ramesh (2006). In addition, the previously studied carbonatites from Tororo and Sukulu complexes (Benkó et al. 2021) are also included (semitransparent). shows that $\sim 1-2 \%$ assimilation of Archean basement can generate $\mathrm{Sr}-\mathrm{Nd}$ isotopic signature of Tororo carbon-
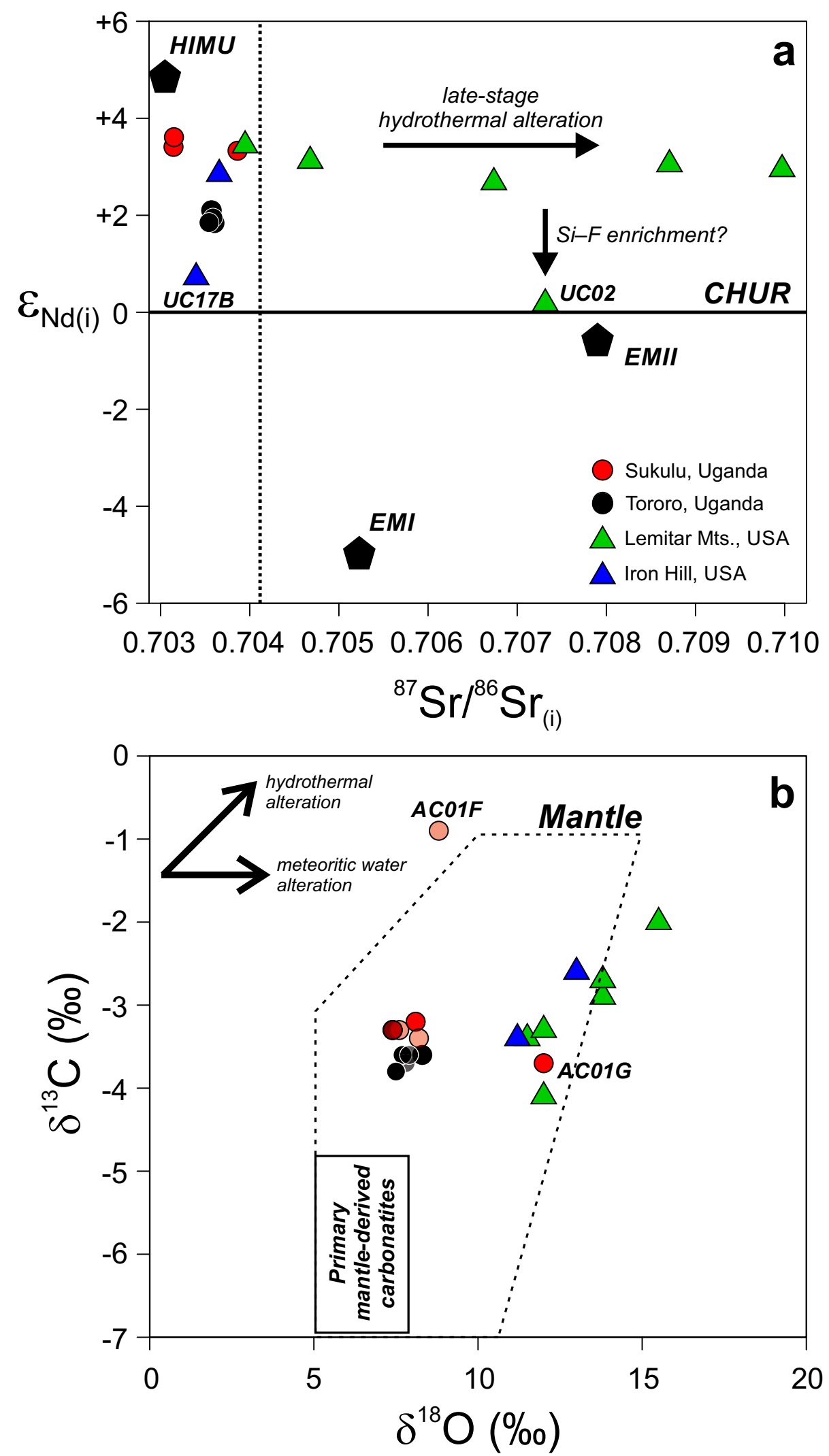

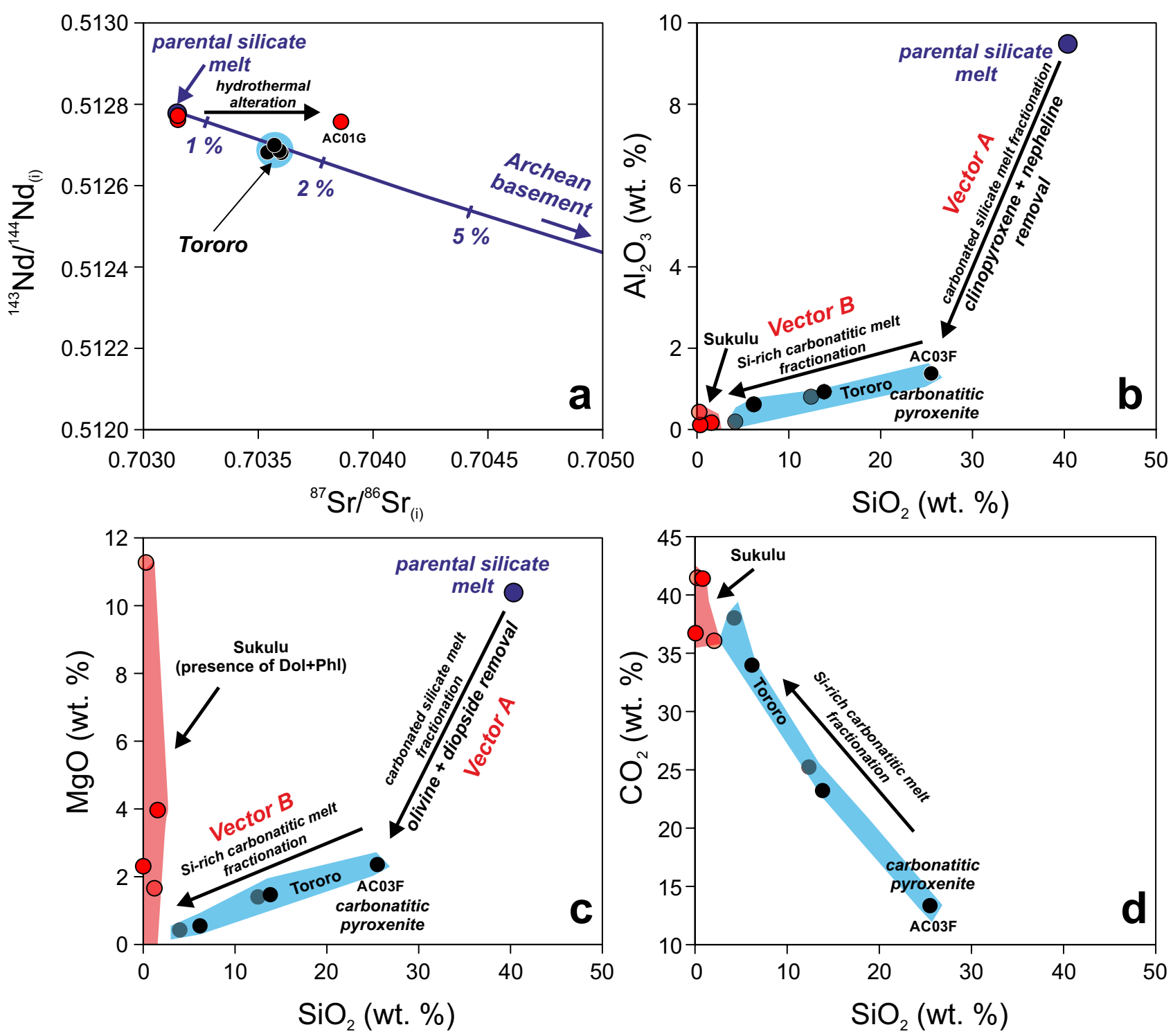

Fig. 9 Major-element and $\mathrm{Sr}-\mathrm{Nd}$ isotopic compositional trends of silicocarbonatites-carbonatites from Tororo and Sukulu complexes. a - Initial ${ }^{143} \mathrm{Nd} /{ }^{144} \mathrm{Nd}$ vs. ${ }^{87} \mathrm{Sr} /{ }^{86} \mathrm{Sr}$ diagram with a trend illustrating mixing between suggested parental silicate melt (olivine nephelinite; Simonetti and Bell 1994) and local Archean basement (Padoan et al. 2011). b-d - Variations of selected major-element $\left(\mathrm{Al}_{2} \mathrm{O}_{3}, \mathrm{MgO}_{2} \mathrm{CO}_{2}\right)$ contents vs. SiO $($ wt. $\%$ ) with trends illustrating mode and style of parental silicate melt fractionation. The major-element data from the previously studied carbonatites of the Tororo and Sukulu complexes (Benkó et al. 2021) are also included (semitransparent).

atites (Fig. 9a). Progressive fractionation of the parental melt (e.g., removal of olivine, diopside-augite, nepheline $\pm \mathrm{Fe}-\mathrm{Ti}$ oxide; Fig. $9 \mathrm{~b}-\mathrm{c}$, Vector A) in combination with the assimilation of late Archean, presumably Na-rich continental crust (e.g., Link et al. 2010) results in the formation of $\mathrm{Na}-\mathrm{K}-\mathrm{Ti}-\mathrm{S}-\mathrm{P}-$ rich silicocarbonatitic melt, here represented by sample AC03F with a composition of carbonatitic pyroxenite (Fig. 9, ESM 5), and the ijolitemelteigite-nepheline syenite residue forming the rim of the Tororo Complex (Fig. 1b). Further evolution of such a silicocarbonatite melt would lead to increasing concentration of $\mathrm{CO}_{2}$ and a further decrease in $\mathrm{MgO}$ (Fig. 9c-d, Vector B) and, finally, crystallization of "pure" low-alkali calcio-carbonatitic (e.g., AC03B) and silicate melt (rich in sulfur) through the process of liquid immiscibility. This latter stage is evidenced by the presence of pockets with variable mineralogy (e.g., Aeg $+\mathrm{Ap} \pm \mathrm{Qz} \pm \mathrm{Dol} \pm \mathrm{Po}$ in sample AC03C; Fig. 3f). This evolutionary trend can also be illustrated by the change in modal proportion and chemistry of crystallizing clinopyroxene and K-feldspar starting with abundant aegirine-augite clinopyroxene + K-feldspar (carbonatitic pyroxenite sample AC03F; Fig. 5) and terminating with only rare aegirine-augite rimmed by $\mathrm{K}$-feldspar (carbonatite AC03B). It is also expressed by increasing $\mathrm{Na}$ content in clinopyroxene from the silicate pockets (Ae 78-87 mol. \%; ESM 3) compared to the matrix (Ae 51-63 mol. \%; ESM 3) found in sample AC03C (Fig. 5). The overall enrichment 
of $\mathrm{Na}$ in Tororo is also documented by the presence of $\mathrm{Na}$-rich bicarbonate fluid inclusions detected in apatite (Benkó et al. 2021). Finally, fluid-removal expressed by the overall decrease in $\mathrm{K}_{2} \mathrm{O}$ from silica-rich carbonatite towards "pure" carbonatite is documented by the presence of fenitized pyroxenite and syenite at the aureole of Tororo carbonatite body with up to 6 wt. $\% \mathrm{~K}_{2} \mathrm{O}$ (e.g., Bell and Doyle 1971).

At the Lemitar Mts., silica-rich carbonatites represent a typical lithology with two types distinguished by their mineralogy and geochemistry - primary magmatic and replacive. The latter is a product of carbonatized silicate rocks (McLemore 1987). Here, we focus on primary silica-rich carbonatites (high in $\mathrm{P}_{2} \mathrm{O}_{5}$, but low in total $\mathrm{FeO}$ ), which predominantly consist of calcite, dolomite, mica, and apatite (see above). While the decoupled $\mathrm{Sr}-\mathrm{Nd}$ isotopic signature and a broadly positive trend between $\delta^{13} \mathrm{C}$ and $\delta^{18} \mathrm{O}$ (Fig. 8b) as well as some of the traceelement systematics (e.g., $\mathrm{Zr}-\mathrm{Y}-\mathrm{Th}-\mathrm{U}$ enrichment; ESM 5) are indicative of late-stage silicification/alteration (e.g., Andersen 1987), the texture and mineralogy of major rock-forming minerals (carbonate, phlogopite) appear to be primary (see Petrography section 4 above). At first sight, these rocks show some similarities to the Sukulu suite in being exceptionally rich in $\mathrm{MgO}$ and $\mathrm{K}_{2} \mathrm{O}$ (1.8-9.6 wt. \% and $0.21-0.77$ wt. \%, respectively) due to the presence of variable quantities of phlogopite with similar Mg\# values (Fig. 4) and dolomite (Fig. 6c). This suggests a possibly similar evolutionary stage of carbonated $\mathrm{Mg}-\mathrm{K}$-rich parental silicate melt. However, in comparison to Sukulu, the process of the liquid immiscibility of a carbonatitic melt from parental carbonated silicate melts is well documented at the Lemitar Mts. silica-rich carbonatites (e.g., sample UC09) by the presence of primary mineral pockets containing zoned Dol + Qz (Fig. 6d).

Finally, detailed petrography of the Iron Hill carbonatites (Fig. 6f) and major-element geochemistry (ESM 5) revealed that the silicocarbonatite UC17B shows remarkably similar characteristics to Tororo silica-rich carbonatites such as high bulk-rock alkali contents reflecting the presence of diopside-aegirineaugite and K-feldspar, in particular in the silicate-rich bands (Fig. 6f). Yet, clinopyroxene from the Iron Hill is strongly zoned, having diopside-augite cores and aegirine rims (Fig. 5). This feature is also described from other silicocarbonatites (Reguir et al. 2012; Viladkar 2017), documenting the progressive enrichment in $\mathrm{Na}$ with progressive crystallization of parental silicate melt.

Based on combined observations from petrography and mineral chemistry and similarities among the three mutually independent suites (Sukulu-Tororo in EARS, Lemitar Mts. and Iron Hill), we propose a general model for the petrogenesis of silicocarbonatite-silica-rich carbonatite-carbonatite association. The alkali and volatile $\left(\mathrm{CO}_{2}-\mathrm{H}_{2} \mathrm{O} \pm \mathrm{F}\right)$-rich, Si-undersaturated parental silicate melts (e.g., olivine nephelinite) underwent fractional crystallization leading to the precipitation of olivine, clinopyroxene, nepheline, Fe-Ti oxides (Fig. 9b-c) and producing the $\mathrm{CO}_{2}+\mathrm{H}_{2} \mathrm{O}-\mathrm{F}$-rich residual melts impoverished in $\mathrm{SiO}_{2}$ and $\mathrm{Al}_{2} \mathrm{O}_{3}$ (Fig. 10). The subsequent evolution would depend on $\mathrm{SiO}_{2}, \mathrm{Na}_{2} \mathrm{O}, \mathrm{K}_{2} \mathrm{O}$ and water contents, $\mathrm{Mg} \#$ of the residual melt, $\mathrm{fO}_{2}$ conditions, and melt ascent efficiency. The high $\mathrm{Mg} \#$, low $\mathrm{Na}_{2} \mathrm{O}$ and enhanced but the variable activity of water (expressed by up to 2.3 wt. $\%$ of $\mathrm{H}_{2} \mathrm{O}^{+}$determined Sukulu carbonatites; ESM 5) would lead to precipitation of variable amounts of Mg-rich phlogopite (2-6 modal \%; ESM 1) and formation of Sukulu, and the Lemitar Mts. "wet" silica-rich carbonatites. In contrast, low $\mathrm{Mg} \#$ paralleled by the prevalence of $\mathrm{Na}_{2} \mathrm{O}$ over $\mathrm{K}_{2} \mathrm{O}$, increasing $f \mathrm{O}_{2}$ expressed by the presence of aegirine and a slow ascent of the melt (possibly associated with crustal contamination) would lead to the olivine removal and the crystallization of aegirine-augite (Tororo) and finally, aegirine (Iron Hill). The product would be "dry" silica-rich carbonatites with negligible phlogopite contents $(\leq 0.5$ modal \%). This clinopyroxene evolutionary trend indicates progressively oxidizing conditions of the melt (e.g., Viladkar 2017). The origin of a "dry" suite is connected to a slow ascent of parental melts, which might also be associated with concomitant assimilation of crustal material (Na-rich?), as observed in Tororo, and $\mathrm{H}_{2} \mathrm{O}$ fluid escape (Fig. 10) documented by predominantly "dry" mineral assemblage. The presence of K-feldspar and absence of leucite in a "dry" suite points to the overall low temperature of Tororo carbonatitic melts (Petrushin et al. 2004) that might be facilitated by high fluorine contents (Jago and Gittins 1991) that were indeed detected (ESM 5). In both cases, further increase of $\mathrm{CO}_{2}$ will ultimately lead to liquid immiscibility, separation of low-alkali carbonatitic melts, and predominant crystallization of either calcite (Tororo), dolomite-calcite (Sukulu, Lemitar Mts.), or ankerite \pm calcite (Iron Hill) depending on $\mathrm{Ca}-\mathrm{Mg}-\mathrm{Fe}$ contents of the parental melt. Therefore, the parental carbonated silicate melts with high $\mathrm{Mg} / \mathrm{Fe}$ will lead to the formation of the calcio- and magnesio-carbonatite association, whereas low $\mathrm{Mg} / \mathrm{Fe}$ melts will form calcio- and ferro-carbonatite association (Fig. 7a). Alternatively, calcio-carbonatites at Sukulu may also be formed by a crystal accumulation from the hydrous magnesio-carbonatite melt (Lee and Wyllie 1998). The presence of quartz in the textural equilibrium with calcite + dolomite and dolomite observed in silicate-carbonate pockets within Tororo and Lemitar Mts. silica-rich carbonatites (Figs 3 and 6), respectively, may indicate local Si-supersaturation of the silica-rich carbonatitic melt. 


\section{Conclusions}

Petrography, major- and trace-element chemistry, as well as $\mathrm{Sr}-\mathrm{Nd}-\mathrm{C}-\mathrm{O}$ isotopic compositions of the carbonatitesilica-rich carbonatite-silicocarbonatite rock associations from four different suites (Sukulu, Tororo - Uganda; Lemitar Mts., Iron Hill - USA) are reported in order to

better understand the role of silica-rich carbonatites in the evolution of carbonatitic magmas. The Sukulu carbonatites are characterized by typically lower $\mathrm{SiO}_{2}$ contents $(<10$ wt. $\%)$ and their overall Mg-rich nature is expressed by the presence of phlogopite \pm olivine. By contrast, the Tororo carbonatites yield a much higher range of $\mathrm{SiO}_{2}$ contents (6.2-13.8 wt. \%) and high alkali and Fe contents

\section{"wet" (Phl-bearing) carbonatites (Sukulu, Lemitar)}

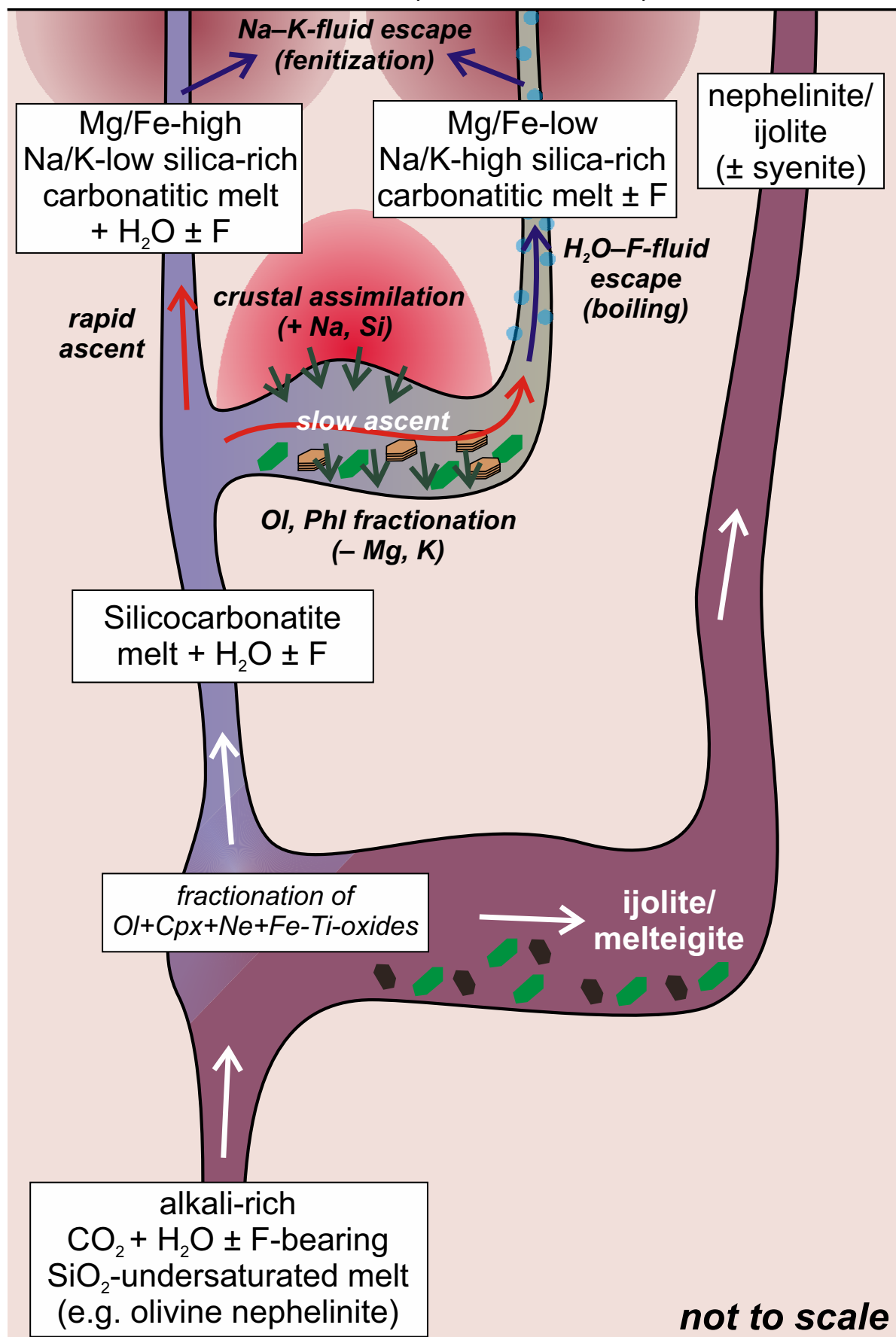
expressed by the presence of aegirine-augite/K-feldspar that might be related to the assimilation of basement lithologies as evidenced from $\mathrm{Sr}-\mathrm{Nd}$ isotopic signatures. These observations combined with detailed petrography suggest that formation of carbonatitic magmas at both sites was intimately connected with progressive fractionation of parental silicate melts and carbonate melt segregation through the liquid immiscibility documented by the presence of silicate-carbonate pockets. The Tororo/Iron Hill and Sukulu/ Lemitar Mts. carbonatites show remarkably similar mineralogy and major-element composition, which indicates a similar evolution of these suites. Therefore, we present a new general model for the origin of silicocarbonatites-silica-rich carbonatite-carbonatite associations, where the fractionation of parental carbonated (and $\mathrm{H}_{2} \mathrm{O}-$ F-bearing) silicate melts would lead to silicate-carbonate melt separation. Its further evolution would depend on $\mathrm{Si}-\mathrm{Na}-\mathrm{K}-\mathrm{Mg}$ contents, water activity, and melt ascent rate.

In addition, the proposed model may explain contrasting petrogenetic signatures of spatially related coupled carbonatite complexes in terms of different ascent rates. Whereas the rapidly ascending magmas

Fig. 10 General model for the petrogenesis of silicocarbonatite-silica-rich carbonatite-carbonatite association. Aeg - aegirine, Cpx - clinopyroxene, $\mathrm{Ne}$ - nepheline, Ol - olivine, Phl phlogopite. 
would preserve the original mantle signature, the slower ascending melts may be affected by more complex fractionation and assimilation processes gaining a more crustal-like signature during its ascent.

Acknowledgments. This research was supported by the Czech Science Foundation (project No. 19-29124X), the Grant Agency of the Charles University (project no. 192218), and the institutional supports RVO67985831 of the Institute of Geology of the Czech Academy of Sciences and Center for Geosphere Dynamics (UNCE/ SCI/006). We thank Elena Antalová and Tereza Grabmüllerová for their help with chemical analyses and John Hora for TIMS analyses, all from the Czech Geological Survey. The manuscript benefits from the two reviews provided by an anonymous reviewer and Ralf Halama and the careful editorial handling of Vojtěch Janoušek.

Electronic supplementary material. Supplementary tables 1 to 6 providing details on sample locations, mineral and whole-rock chemistry are available online at the Journal web site (http://dx.doi.org/10.3190/jgeosci.320).

\section{References}

ACKERMAN L, MAGNA T, RAPPRICH V, UPADHYAY D, KRÁTKÝ O, Čejková B, Erban V, Kochergina YV, Hrstka $\mathrm{T}$ (2017) Contrasting petrogenesis of spatially related carbonatites from Samalpatti and Sevattur, Tamil Nadu, India. Lithos 284-285: 257-275

ACKERMAN L, ŽÁK K, SKÁla R, REJŠEK J, KŘíŽOvá Š, WimPENNY J, MAGNA T (2020) Sr-Nd-Pb isotope systematics of Australasian tektites: Implications for the nature and composition of target materials and possible volatile loss of $\mathrm{Pb}$. Geochim Cosmochim Acta 276: 135-150

Andersen T (1987) Mantle and crustal components in a carbonatite complex, and the evolution of carbonatite magma: REE and isotopic evidence from the Fen Complex, southeast Norway. Chem Geol 65: 147-166

Bell K, Blenkinsop J (1987) Nd and Sr isotopic compositions of East African carbonatites: Implications for mantle heterogeneity. Geology 15: 99-102

BeLl K, DoYle RJ (1971) K-Rb relationships in some continental alkalic rocks associated with the East African Rift Valley System. Geochim Cosmochim Acta 35: 903-915

Bell K, Keller J (1995) Carbonatite Volcanism. Oldoinyo Lengai and the Petrogenesis of Natrocarbonatites. IAVCEI Proceedings in Volcanology Series 4: pp $1-210$

Bell K, Simonetti A (1996) Carbonatite magmatism and plume activity: Implications from the $\mathrm{Nd}, \mathrm{Pb}$ and $\mathrm{Sr}$ isotope systematics of Oldoinyo Lengai. J Petrol 37: 1321-1339
Bell K, Simonetti A (2010) Source of parental melts to carbonatites - Critical isotopic constraints. Mineral Petrol 98: 77-89

Benkó Z, Molnár K, Magna T, Rapprich V, Palcsu L, Pour O, Čejková B, Futó I, Czuppon G (2021) Combined petrography, noble gas, stable isotope and fluid inclusion chemistry of carbonatites from Uganda: Implications for the origin of the carbonatite melt in continental rift setting. Chem Geol 578, article 120213: 10.1016/j.chemgeo.2021.120213

Bizzarro M, Simonetti A, Stevenson RK, David J (2002) Hf isotope evidence for a hidden mantle reservoir. Geology 30: 771-774

BLOOMFIELD K (1973) Economic aspects of Uganda carbonatite complexes. Overseas Geol Miner Resour 41: 139-167

BROOKER RA, KJARSGAARD BA (2011) Silicate-carbonate liquid immiscibility and phase relations in the system $\mathrm{SiO}_{2}-\mathrm{Na}_{2} \mathrm{O}-\mathrm{Al}_{2} \mathrm{O}_{3}-\mathrm{CaO}-\mathrm{CO}_{2}$ at $0.1-2.5 \mathrm{GPa}$ with applications to carbonatite genesis. J Petrol 52: 1281-1305

Chandra J, Paul D, Stracke A, Chabaux F, Granet M (2019) The origin of carbonatites from Amba Dongar within the Deccan Large Igneous Province. J Petrol 60: 1119-1134

DAviEs KA (1965) The Geology of Part of South-East Uganda, with Special Reference to the Alkaline Complexes, Geological Survey of Uganda, Memoirs 8: 1-76

Dempírová L, ŠIKL J, KašIČKová R, Zoulková V, KŘíBEK $\mathrm{B}$ (2010) The evaluation of precision and relative error of the main components of silicate analyses in Central Laboratory of the Czech Geological Survey. Zprávy Geol Výzk 2009 27: 326-330 (in Czech with English summary)

ERnst RE, BELL K (2010) Large igneous provinces (LIPs) and carbonatites. Mineral Petrol 98: 55-76

FAN HR, YANG KF, Hu FF, LIU S, WANG KY (2016) The giant Bayan Obo REE-Nb-Fe deposit, China: Controversy and ore genesis. Geosci Front 7: 335-344

GitTins J (1989) The origin and evolution of carbonatite magmas. In: BELL K (ed) Carbonatites: Genesis and Evolution. Unwin Hyman, Winchester, Mass., pp 580-600

GitTins J, HARMER RE, BARKer DS (2005) The bimodal composition of carbonatites: Reality or misconception? Lithos 85: 129-139

Halama R, Vennemann T, Siebel W, Markl G (2005) The Grønnedal-Ika Carbonatite-Syenite Complex, South Greenland: carbonatite formation by liquid immiscibility. J Petrol 46: 191-217

HARTE B (1988) Heterogeneous mantle domains: Signatures, genesis and mixing chronologies. Earth Planet Sci Lett 90: 273-296

JAGo BC, GitTins J (1991) The role of fluorine in carbonatite magma evolution. Nature 349: 56-58

JANOUŠEK V, FARROW CM, ERBAN V (2006) Interpretation of whole-rock geochemical data in igneous geochemis- 
try: Introducing Geochemical Data Toolkit (GCDkit). J Petrol 47: 1255-1259

Jones AP, Genge M, Carmody L (2013) Carbonate melts and carbonatites. In: HAZEN K, JONES AP, BARoss AJ (eds) Carbon in Earth. Reviews in Mineralogy and Geochemistry 75: 289-322

KJARSGAARD BA (1989) Phase relations of a carbonated high-CaO nephelinite at 0.2 and $0.5 \mathrm{GPa}$. J Petrol 39: 2061-2075

KySER TK (1990) Stable isotopes in the continental lithospheric mantle. In: Menzies MA (ed) The Continental Lithosphere. Oxford University Press, Oxford, pp 127-156

LeE WJ, WiLley PJ (1994) Experimental data bearing on liquid immiscibility, crystal fractionation, and the origin of calciocarbonatites and natrocarbonatites. Int Geol Rev 36: 797-819

Lee WJ, Willey PJ (1998) Processes of crustal carbonatite formation by liquid immiscibility and differentiation, elucidated by model systems. J Petrol 39: 2005-2013

Le Maitre, RW (ed) (2002) Igneous rocks. A Classification and Glossary of Terms, $2^{\text {nd }}$ Edition. Cambridge University Press, Cambridge, pp 1-236

LEGGO PJ (1974) A geochronological study of the basement complex of Uganda. J Geol Soc, London 130: 263-277

Link K, Koehn D, Barth MG, Tiberindwa JV, BarifaiJo E, Aanyu K, Foley SF (2010) Continuous cratonic crust between the Congo and Tanzania blocks in western Uganda. Int J Earth Sci 99: 1559-1573

Lustrino M, LuCiani N, Stagno V (2019) Fuzzy petrology in the origin of carbonatitic/pseudocarbonatitic Ca-rich ultrabasic magma at Polino (central Italy). Sci Rep 9: 1-14

Lustrino M, Ronca S, Caracausi A, Ventura Bordenca C, Agostini S, Faraone DB (2020) Strongly $\mathrm{SiO}_{2}$-undersaturated, $\mathrm{CaO}$-rich kamafugitic Pleistocene magmatism in Central Italy (San Venanzo volcanic complex) and the role of shallow depth limestone assimilation. Earth-Sci Rev 208: 103256

Magna T, Viladkar S, Rapprich V, Pour O, Hopp J, ČEJKová B (2020) Nb-V-enriched sövites of the northeastern and eastern part of the Amba Dongar carbonatite ring dike, India - a reflection of post-emplacement hydrothermal overprint? Geochemistry 80: article 125534; doi: 10.1016/j.chemer.2019.125534

MCCREA JM (1950) On the isotope chemistry of carbonates and a paleotemperature scale. J Chem Phys 18: 849-857

McDonough WF, Sun S (1995) The composition of the Earth. Chem Geol 120: 223-253

MCLeMORE VT (1982) Geology and geochemistry of the Ordovician carbonatite dikes in Lemitar Mountains, Socorro County, New Mexico. New Mexico Bureau of Geology and Mineral Resources Open File Reports 158: 1-104

McLemORe VT (1987) Geology and regional implications of carbonatites in the Lemitar Mountains, central New Mexico. J Geol 95: 255-270
McLemore VT, Moderski J (1990) Mineralogy and geochemistry of altered rocks associated with Lemitar carbonatites, central New Mexico, U.S.A. Lithos 26: 99-113

McMillan NJ, McLemore VT (2004) Cambrian-Ordovician magmatism and extension in New Mexico and Colorado. New Mexico Bureau of Geology and Mineral Resources Bulletin 160: 1-12

Mitchell RH (2005) Carbonatites and carbonatites and carbonatites. Canad Mineral 43: 2049-2068

Mitchell RH (2015) Primary and secondary niobium mineral deposits associated with carbonatites. Ore Geol Rev 64: 626-641

Morimoto N (1988) Nomenclature of pyroxenes. Mineral Mag 52: 535-550

NASH WP (1972) Mineralogy and petrology of the Iron Hill Carbonatite Complex, Colorado. Geol Soc Am Bull 83: 1361-1382

Nelson DR, Chivas AR, Chappell BW, McCulloch MT (1988) Geochemical and isotopic systematics in carbonatites and implications for the evolution of ocean-island sources. Geochim Cosmochim Acta 52: 1-17

Olson JC, Marvin RF, Parker RL, Mehnert HH (1977) Age and tectonic setting of lower Paleozoic alkalic and mafic rocks, carbonatites, and thorium veins in southcentral Colorado. J Res US Geol Surv 5: 673-687

Padoan M, Garzanti E, Harlavan Y, Villa IM (2011) Tracing Nile sediment sources by $\mathrm{Sr}$ and Nd isotope signatures (Uganda, Ethiopia, Sudan). Geochim Cosmochim Acta 75: 3627-3644

Petrushin EI, Bazarov LS, Sharygin VV, Gordeeva VI, VLADYKIN NV (2004) Effect of temperature regime on crystallization of leucite from orendite melt. Russ Geol Geophys 45: 1208-1215

Pin C, Gannoun A, Dupont A (2014) Rapid, simultaneous separation of $\mathrm{Sr}, \mathrm{Pb}$, and $\mathrm{Nd}$ by extraction chromatography prior to isotope ratios determination by TIMS and MC-ICP-MS. J Anal At Spectrom 29: 1858-1870

RAJA PKS, VISE JB (1973) Palaeomagnetism of the Tororo ring complex, S.E. Uganda. Earth Planet Sci Lett 19: 438-442

RAY JS, RAMESH R (2006) Stable carbon and oxygen isotopic compositions of Indian carbonatites. Int Geol Rev 48: $17-45$

REEDMAN JH (1984) Resources of phosphate, niobium, iron, and other elements in residual soils over the Sukulu Carbonatite Complex, southeastern Uganda. Econ Geol 79: 716-724

Reguir EP, ChaKhmouradian AR, Halden NM, Malkovets VG, YANG P (2009) Major- and trace-element compositional variation of phlogopite from kimberlites and carbonatites as a petrogenetic indicator. Lithos 112: 372-384

Reguir EP, Chakhmouradian AR, Pisiak L, Halden NM, YANG P, Xu C, KynickÝ J, CouësLAN CG (2012) Trace-element composition and zoning in clinopyroxene- and amphibole-group minerals: Implications for 
element partitioning and evolution of carbonatites. Lithos 128-131: 27-45

Sarbas B, Jochum KP, Nohl U, Weis U (2017) The geochemical databases GEOROC and GeoReM - What's new? American Geophysical Union, Fall Meeting 2017, abstract \# V23D-0501

Simonetti A, Bell K (1994) Nd, Pb and Sr isotopic data from the Napak carbonatite-nephelinite centre, eastern Uganda: An example of open-system crystal fractionation. Contrib Mineral Petrol 115: 356-366

VeKsler IV, Nielsen TFD, SoKolov SV (1998) Mineralogy of crystallized melt inclusions from Gardiner and Kovdor ultramafic alkaline complexes: Implications for carbonatite genesis. J Petrol 39: 2015-2031

ViETEN K, HAMм HM (1978) Additional notes on the calculation of the crystal chemical formula of clinopyroxenes and their contents of $\mathrm{Fe}^{3+}$ from microprobe analyses. Neu Jb Mineral, Mh 2: 71-83

VILADKAR SG (2000) Phlogopite as an indicator of magmatic differentiation in the Amba Dongar carbonatite, Gujarat, India. Neu Jb Mineral, Abh 7: 302-314

VILADKAR SG (2017) Pyroxene-sövite in Amba Dongar carbonatite-alkalic complex, Gujarat. J Geol Soc India 90: 591-594

WOOLLEY AR (1982) A discussion of carbonatite evolution and nomenclature and the generation of sodic and potassic fenites. Mineral Mag 46: 13-17

Ying J, Zhou X, Zhang H (2004) Geochemical and isotopic investigation of the Laiwu-Zibo carbonatites from western Shandong Province, China, and implications for their petrogenesis and enriched mantle source. Lithos 75: 413-426 